\title{
Retinal and epiretinal glia-an immunohistochemical study
}

\author{
P. S. HISCOTT,' I. GRIERSON,' C. J. TROMBETTA,' A. H. S. RAHI,' \\ J. MARSHALL,, AND D. MCLEOD 3
}

From the 'Department of Pathology, and 'Department of Clinical Ophthalmology, Institute of Ophthalmology, London, and the ${ }^{3}$ Surgical Vitreoretinal Unit, Moorfields Eye Hospital, London

SUMMARY Immunohistochemical techniques were used to examine the distribution of cells containing glial fibrillary acidic protein (GFAP) in normal and pathological human specimens, including 22 globes (13 of which contained epiretinal membranes 'in situ'), 16 surgically excised epiretinal membranes, and monolayers of cells obtained from five epiretinal membranes placed in tissue culture. The astrocytic cells of normal and pathological retinae stained with the glial-cell marker, but Müller cells were GFAP-negative in normal retinae at the antisera dilutions used. Müller cells did, however, stain in retinae from glaucomatous eyes and in eyes with prolonged retinal detachment. Electron microscopy did not reveal any obvious morphological difference between the intermediate filaments of normal (GFAP-negative) and GFAP-positive Müller cells. Ten of the 13 epiretinal membranes 'in situ', all 16 excised membranes, and three of the five monolayers contained glial cells. Purely glial membranes were not associated with retinal puckering or detachment, while all membranes causing tractional complications had a prominent fibrous, non-glial component. Our findings suggest that glial cells do not contribute significantly to the contractile forces generated by epiretinal membranes. They may, however, provide a scaffold on which other cells proliferate and contract and an anchorage by means of which tangential forces are transmitted into and through the retina.

Müller cells can be recognised easily by conventional morphological and ultrastructural techniques, but other types of retinal glia are far more difficult to identify. Neuroglial stains, such as the modified del Rio Hortega method, have been used to study the distribution of accessory glial cells in the normal retina, ${ }^{\prime}$ but these stains lack specificity ${ }^{2}$ and often produce inconsistent results. ${ }^{34}$ Fortunately immunohistochemical techniques are available which employ antibodies against structural proteins in the cytoskeleton of glial cells. One such protein-glial fibrillary acidic protein (GFAP) -is unique to glia. Thus, immunostains developed against this protein are an extremely accurate and reproducible means of locating glial cells in neural tissues. Anti-GFAP staining has been used to investigate the distribution of glia in the normal retina of several species including man. ${ }^{5-7}$

Correspondence to Dr P. Hiscott, Pathology Department, Institute of Ophthalmology, 17/25 Cayton Street, London EC1V 9AT.
Retinal glia appear to be a component of cellular proliferations which develop on the retinal surfaceepiretinal membranes (ERMs). ${ }^{8}-22$ To date, recognition of glia in ERMs has been based mainly on conventional histological and ultrastructural criteria. However, the cellular constituents of ERMs are activated or metaplastic and are displaced from their normal location. It is notoriously difficult to identify the origins of such ectopic cells on morphological characteristics alone. Since glial cells may have important functional activities in ERMs, it is desirable to identify glia more accurately than has been possible in the past. Three ERMs removed at surgery for massive periretinal proliferation (MPP) have recently been described after immunohistochemical staining using antibodies against GFAP. ${ }^{23}$ We have used a similar immunohistochemical approach to identify glia in a much larger series of specimens including sections $(a)$ from normal globes, $(b)$ from eyes containing ERMs, and (c) from surgically excised 
membranes. Monolayers of cells grown from ERMs in tissue culture were also studied.

\section{Materials and methods}

Controls. Sections of normal human brain and optic nerve served as controls to confirm the specificity of our technique. In addition sections from two known optic nerve astrocytomas were used as standards in each immunohistochemical procedure. Monolayers of cells grown in tissue culture, including monolayers of retinal astrocytes, various ocular epithelia, and fibroblasts from normal human, bovine, and rabbit eyes, provided further positive and negative controls for the immunohistochemical methods employed in this investigation.

Normal globes. In order to study the distribution of glia in the normal retina six globes were obtained from the Moorfields eye bank having been removed from donors within 24 hours post mortem. The donors' ages ranged from 14 to 66 years.

Globes with elevated intraocular pressure. The glial distribution in the retinae of three globes enucleated for anterior segment tumours with secondary eleva- tion of intraocular pressure were investigated because some of our series of pathological globes containing ERMs were glaucomatous.

Globes with epiretinal membranes in situ. Thirteen globes known to contain non-vascularised ERMs were studied. Four of the eyes contained an attached retina, two had localised retinal puckering, and the remaining seven had a total retinal detachment. They were associated with a range of pathological conditions (Table 1). Four of these globes had had elevated intraocular pressure.

Excised epiretinal membranes. Sixteen specimens were obtained during closed pars-plana microsurgery (Table 2). Ten membranes had been associated with macular pucker and six were representative of more diffuse proliferations (MPP).

Tissue culture monolayers. Five peeled macular membranes were placed in tissue culture (Table 2), and monolayers of cells were obtained for immunofluorescent investigation by a method previously described. ${ }^{24}$

TRANSMISSION ELECTRON MICROSCOPY (TEM) We compared the stability of the GFAP-containing

Table 1 Details of 13 globes

\begin{tabular}{|c|c|c|c|}
\hline $\begin{array}{l}\text { Histological appearance } \\
\text { of retina }\end{array}$ & Associated pathology & $\begin{array}{l}\text { Intraocular } \\
\text { pressure }\end{array}$ & Summary of immunohistochemical findings \\
\hline \multirow[t]{4}{*}{$\begin{array}{l}\text { No retinal detachment } \\
\text { ( } 4 \text { globes) }\end{array}$} & Central retinal vascular occlusion (Fig. 3) & Elevated & $\begin{array}{l}\text { Glia in diffuse ERMs continuous with GFAP- } \\
\text { positive retinal cells. Haemomacrophages } \\
\text { present }\end{array}$ \\
\hline & $\begin{array}{l}\text { Multiple intraocular surgery for Chandler's } \\
\text { syndrome }\end{array}$ & Elevated & Glial epipapillary membrane \\
\hline & Panuveitis and corneal abscess & - & $\begin{array}{l}\text { Epiretinal glial cells continuous with GFAP- } \\
\text { positive retinal cells. Inflammatory cells } \\
\text { present }\end{array}$ \\
\hline & Endophthalmitis & - & $\begin{array}{l}\text { Epiretinal glial cells continuous with GFAP- } \\
\text { positive retinal cells. Inflammatory cells } \\
\text { present }\end{array}$ \\
\hline \multirow[t]{2}{*}{$\begin{array}{l}\text { Localised retinal } \\
\text { puckering ( } 2 \text { globes) }\end{array}$} & Central retinal vascular occlusion (Fig. 1e, f) & Elevated & $\begin{array}{l}\text { Glial layer on retinal side of fibrous ERM } \\
\text { and glial foci in another fibrous membranc } \\
\text { overlying pucker. Glial ERM overlying un- } \\
\text { distorted retina }\end{array}$ \\
\hline & $\begin{array}{l}\text { Perforating trauma and sympathetic } \\
\text { ophthalmia (Figs. 1c, d, and } 4 a \text { ) }\end{array}$ & - & $\begin{array}{l}\text { Glial layer under and in fibrous ERMs. Glia con- } \\
\text { tinuous with GFAP-positive retinal cells }\end{array}$ \\
\hline \multirow[t]{7}{*}{$\begin{array}{l}\text { Total retinal detachment } \\
\quad(7 \text { globes })\end{array}$} & Rhegmatogenous detachment (MPP) & - & $\begin{array}{l}\text { Glia foci in fibrous ERMs overlying retinal } \\
\text { folds. Pigmented cells present }\end{array}$ \\
\hline & Rhegmatogenous detachment (MPP) & Elevated & $\begin{array}{l}\text { Glial layers in and under fibrous ERMs. Pigment } \\
\text { in some glia }\end{array}$ \\
\hline & Retinal vasculitis & - & $\begin{array}{l}\text { Glia on ILL away from retinal folds and glial } \\
\text { focus in fibrous ERM over retinal fold. Pig- } \\
\text { mented cells present }\end{array}$ \\
\hline & One month after perforating trauma & - & $\begin{array}{l}\text { Fibroglial layered ERM. Glia continuous with } \\
\text { GFAP-positive cells in retina }\end{array}$ \\
\hline & Six weeks after perforating trauma (Fig. 4b) & - & $\begin{array}{l}\text { Fibrous ERM extending from peripheral wound } \\
\text { (GFAP-negative) }\end{array}$ \\
\hline & Endophthalmitis after perforating trauma & - & $\begin{array}{l}\text { Fibrous ERM extending from peripheral wound } \\
\text { (GFAP-negative) }\end{array}$ \\
\hline & Nine days after perforating trauma & 一 & $\begin{array}{l}\text { Fibroblastic and red cells on retinal surface } \\
\text { (GFAP-negative) }\end{array}$ \\
\hline
\end{tabular}


Table 2 Details of 21 excised epiretinal membranes

\begin{tabular}{|c|c|c|c|c|}
\hline Specimens & Associated pathology & $\begin{array}{l}\text { No. of } \\
\text { specimens }\end{array}$ & $\begin{array}{l}\text { No. of specimens } \\
\text { containing glia }\end{array}$ & Note on distribution of glia \\
\hline $\begin{array}{l}\text { Embedded epimacular } \\
\text { membranes (10) }\end{array}$ & $\begin{array}{l}\text { Rhegmatogenous retinal } \\
\text { detachment } \\
\text { Perforating trauma } \\
\text { Blunt trauma } \\
\text { Vascular occlusion }\end{array}$ & $\begin{array}{l}6 \\
2 \\
1 \\
1\end{array}$ & $\begin{array}{l}2 \\
1 \\
1\end{array}$ & $\begin{array}{l}3 \text { in layers, } 2 \text { in foci, } 1 \text { layer plus foci } \\
\text { Cells on ILL } \\
\text { Layer of cells } \\
\text { Scattered throughout membrane }\end{array}$ \\
\hline $\begin{array}{l}\text { Embedded MPP membranes } \\
\text { (6) }\end{array}$ & $\begin{array}{l}\text { Rhegmatogenous retinal } \\
\text { detachment } \\
\text { Retinitis (viral) }\end{array}$ & $\begin{array}{l}5 \\
1\end{array}$ & 5 & $\begin{array}{l}2 \text { in layers, } 2 \text { in foci, } 1 \text { with cells } \\
\text { scattered throughout membrane } \\
\text { Focus of cells }\end{array}$ \\
\hline $\begin{array}{l}\text { Tissue culture monolayers from } \\
\text { epimacular membranes (5) }\end{array}$ & $\begin{array}{l}\text { Rhegmatogenous retinal } \\
\text { detachment } \\
\text { Perforating trauma } \\
\text { Blunt trauma }\end{array}$ & $\begin{array}{l}2 \\
2 \\
1\end{array}$ & $\begin{array}{l}1 \\
1 \\
1\end{array}$ & $\begin{array}{l}\text { ( } 2 \% \text { of total cells glial) } \\
\text { ( } 20 \% \text { of total cells glial) } \\
\text { ( } 5 \% \text { of total cells glial) }\end{array}$ \\
\hline
\end{tabular}

intermediate filaments after different fixation and preparation methods. For this part of the study portions of retinae from normal eyes were taken (i) after formol-saline fixation, (ii) after glutaraldehyde fixation, and (iii) following wax embedding and dewaxing for electron microscopic processing using the method described by Jensen. ${ }^{25}$ In addition portions of retinae from the globes with elevated intraocular pressures were studied to compare the intermediate filament distribution with that in retina at normal IOP. Portions of ERMs were also examined by TEM. Specimens were fixed in $3 \%$ buffered glutaraldehyde, postfixed in $1 \%$ osmium tetroxide, dehydrated in graded alcohol, and embedded in Araldite. Sections $1 \mu \mathrm{m}$ thick were taken from the retinal specimens and ERMs and stained with toluidine blue for light microscopic analysis. Thin sections were stained with uranyl acetate and lead citrate for TEM (Jeol 100C).

\section{SCANNING ELECTRON MICROSCOPY}

Portions of retina from one globe were fixed in 3\% buffered glutaraldehyde, postfixed in $1 \%$ osmium tetroxide, dehydrated in graded alcohols and critical point dried (EMscope). They were coated with gold in a sputter coater (EMscope) and examined with an Hitachi S520 scanning electron microscope.

\section{IMMUNOHISTOCHEMISTRY}

Specimens intended for immunohistochemical study by the immunoperoxidase method were fixed in $10 \%$ formol-saline or 3\% glutaraldehyde and dehydrated in graded alcohol for paraffin wax embedding. We used an immunoperoxidase staining method similar to that reviewed by Mukai and Rosai. ${ }^{26}$ Sections 10 $\mu \mathrm{m}$ thick of wax-embedded tissue, including control tissues, normal, hypertensive, and membranecontaining globes, and eight of the peeled epiretinal membranes were dewaxed and trypsinised for immunoperoxidase staining of glial elements. Endogenous peroxidase activity was blocked with $0.5 \%$ hydrogen peroxidase in methanol. After thorough washing in TRIS buffered saline (TBS), $\mathrm{pH}$ $7 \cdot 6$, the sections were treated with normal swine serum and then incubated for 30 minutes with antiGFAP (DAKO Corporation, California, USA) raised in rabbit and diluted 1:300. Control sections were processed with omission or substitution of the primary antibody. After three washes in TBS they were incubated for 30 minutes with antirabbit antibody raised in swine. After thorough washing with TBS the sections were incubated with horseradish peroxidase-rabbit antihorseradish peroxidase complex (PAP) for 30 minutes and washed for a further half hour. The complex sites were shown brown using 3,3 diaminobenzidine tetrahydrochloride with fresh hydrogen peroxide substrate. The sections were counterstained with Mayer's haematoxylin and mounted for conventional and phase-contrast light microscopy.

Specimens for study by immunofluorescent staining were placed in OCT embedding media (Lab-Tek products, Illinois) and immediately frozen in liquid nitrogen. Sections $7 \mu \mathrm{m}$ thick were cut in a cryostat from eight of the peeled membranes, and portions were air dried on to glass slides for 20 minutes. Monolayers of cells grown in tissue culture were fixed in $10 \%$ formol-saline after the culture media had been thoroughly washed off with phosphate-buffered saline (PBS), $\mathrm{pH} 7 \cdot 6$. The monolayers were treated with $0.025 \%$ saponin for 5 minutes and then rinsed with PBS. Neither the frozen sections nor the cell monolayers survived the immunoperoxidase technique well. Therefore glial components were demonstrated in these specimens by an indirect immunofluorescent technique following a procedure similar to the immunoperoxidase method but omitting trypsinisation and peroxidase blocking. After incuba- 
tion with the primary antibody, sections were washed for 30 minutes with PBS and then incubated with antirabbit fluorescent antibody. After 45 minutes of PBS washing, they were mounted in $10 \%$ buffered glycerol and viewed with an epifluorescent microscope (Zeiss).

\section{Results}

\section{CONTROLS}

Sections of brain showed astrocytic glial cells which stained brown following immunoperoxidase labelling for GFAP. Frozen sections of optic nerve and monolayers of cells in tissue culture showed fluorescence of only the glial component after immunofluorescent marking for glial cells. After omission of the primary antisera the glial components in the controls failed to stain.

GLIA WITHIN THE RETINA

Immunohistochemistry of eye-bank eyes revealed GFAP-positive cells and their processes in the inner layers of the retina, especially in the nerve-fibre and ganglion-cell layers and around blood vessels (Fig. 1a). At the optic disc positively staining tissue continued from the inner retina into the optic nerve. In the peripheral retina positively staining cells were found extending from the internal to the external limiting membranes, especially where post-oral cystoid changes were present. Elsewhere, however, Müller cells and their processes failed to stain at the concentration of antisera used. Formalin fixation gave the best intensity of stain, but glutaraldehyde fixed tissue also gave good differential staining with a similar distribution to that of the formalin fixed tissue.

In the three eyes with elevated intraocular pressure secondary to anterior segment tumours the accessory glia in the inner layers of the retina had an enhanced staining reaction (when compared with that in the normal globes). In addition, the whole network of Müller cells and their processes, from external to internal limiting membranes, was positively stained throughout the retina (Fig. 1b). By electron microscopy the $10 \mathrm{~nm}$ intermediate filaments did not vary in either size or numbers with the various types of fixatives employed (Fig. 2a, b), and the filaments were sufficiently stable to survive the process of dewaxing and embedding for TEM (Fig. 2c).

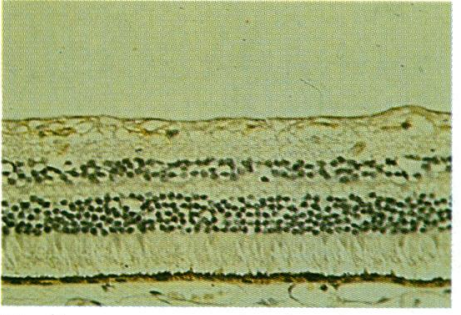

Fig. 1a

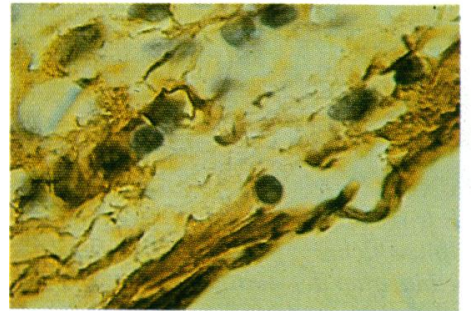

Fig. 1d

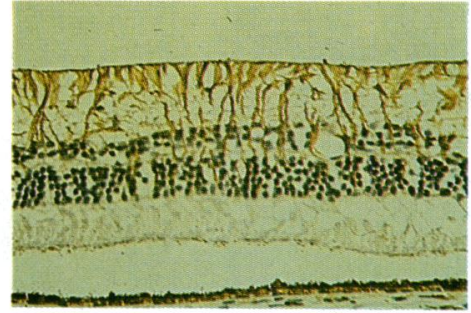

Fig. 1b

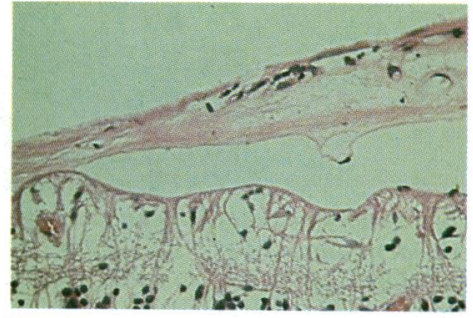

Fig. 1e

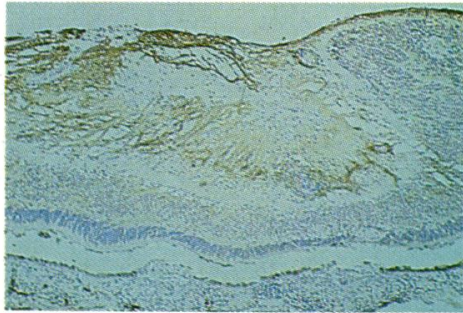

Fig. 1c

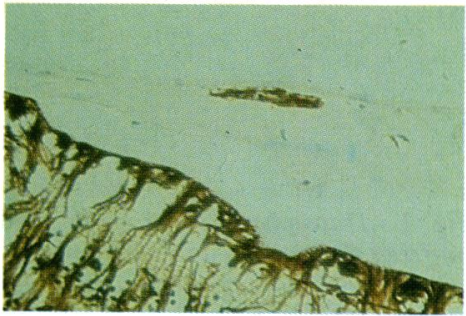

Fig. 1f

Fig. 1 Light micrographs from sections stained with the immunoperoxidase method for GFAP and counterstained with haematoxylin (IP and $H$ ) or haematoxylin and eosin $(H$ and $E)$. (a) Normal human retina. Positive cells (brown reaction products) are found only in the inner retina. (IP and $H, \times 137)$. (b) Retina from an eye with long-standing glaucoma. The staining in the inner retinal layers is more intense than in Fig. Ia and the Müller cells are positively stained. (IP and H, $\times 137)$. (c) A retinal pucker. Note the positive staining Müller cells in the retina and the overlying fibroglial epiretinal membrane with its predominantly GFAP-negative fibroblastic component. (IP and $H, \times 27)$. (d) Glial cells within an epiretinal membrane. Note the filamentous staining pattern in the cells' cytoplasm. (IP and H, $\times 687)$. (e) Retina with an overlying epiretinal membrane. The glial component in the apparently fibrous membrane is not clearly demonstrated. (H and E, $\times 275)$. (f) The same specimen as Fig. Ie). A focus of glial cells within the epiretinal membrane is now apparent after staining for GFAP. (IP and $H, \times 275$ ). 


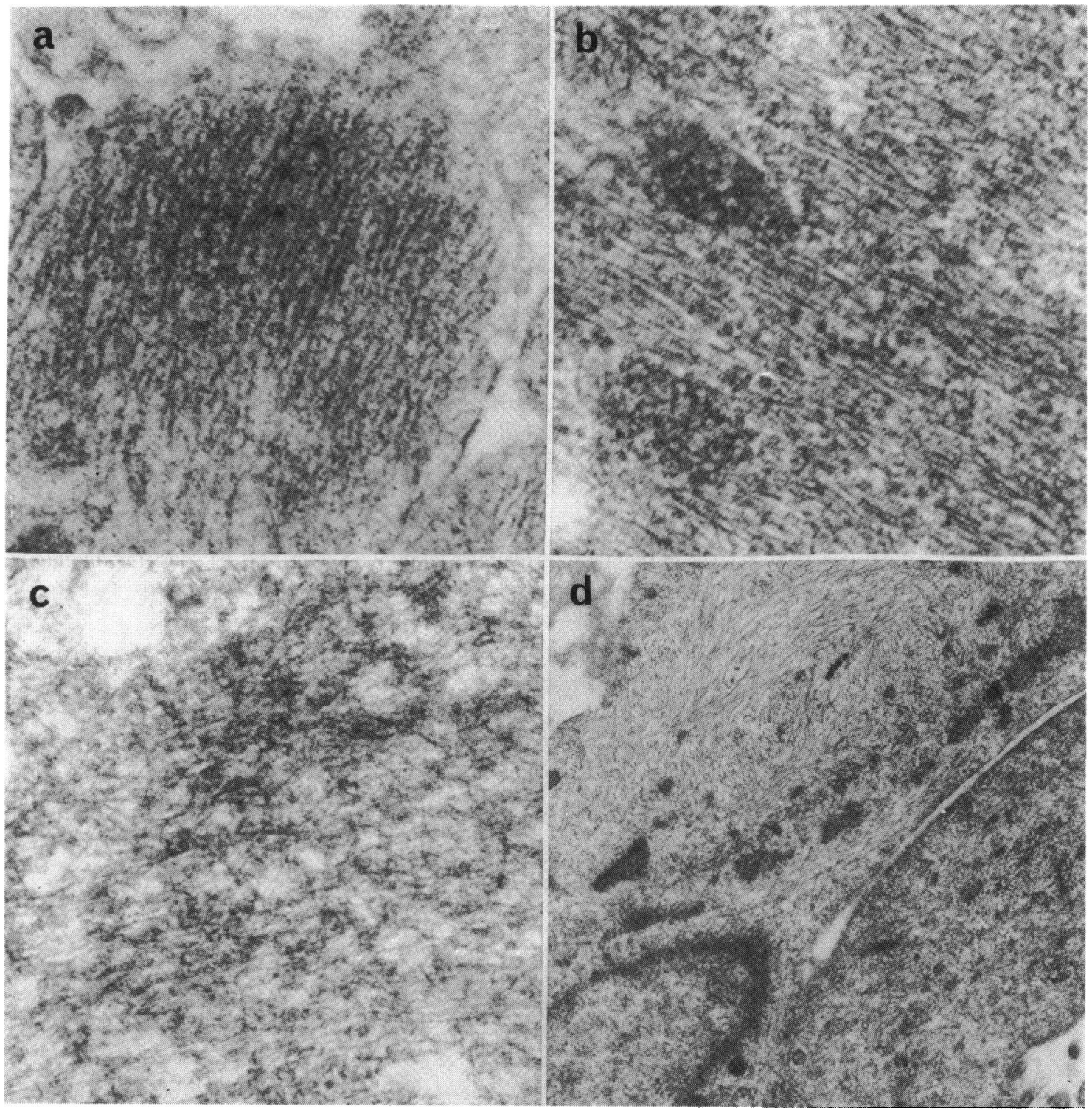

Fig. 2 Transmission electron micrographs of: (a) Intermediate filaments in Müller cells from a retina which was fixed in $3 \%$ buffered glutaraldehyde. (×82350). (b) Intermediate filaments of Müller cells from a retina which was fixed in $10 \%$ formol saline. $(\times 82350)$. (c) Intermediate filaments of Müller cells in $10 \%$ formol saline fixed retina, after dewaxing and re-embedding in Araldite. $(\times 53530)$. (d) Glial cell in epiretinal membrane. The cell contains intermediate filaments. From a specimen which had been fixed in $3 \%$ buffered glutaraldehyde. $(\times 16470)$.

Although the immunoperoxidase staining reaction was positive in Müller cells of glaucomatous eyes, there was no obvious increase in the numbers of filaments nor any change in filament appearance at TEM in these cells.

In all 13 globes containing ERMs the Müller cells were positively staining to GFAP at the antisera dilution used (Fig. 1c). This staining pattern was similar to that seen in the three globes with elevated pressure secondary to anterior segment tumours.

GLIA WITHIN EPIRETINAL MEMBRANES

Enucleated globes. Immunohistochemical analysis revealed that the four epiretinal membranes which 

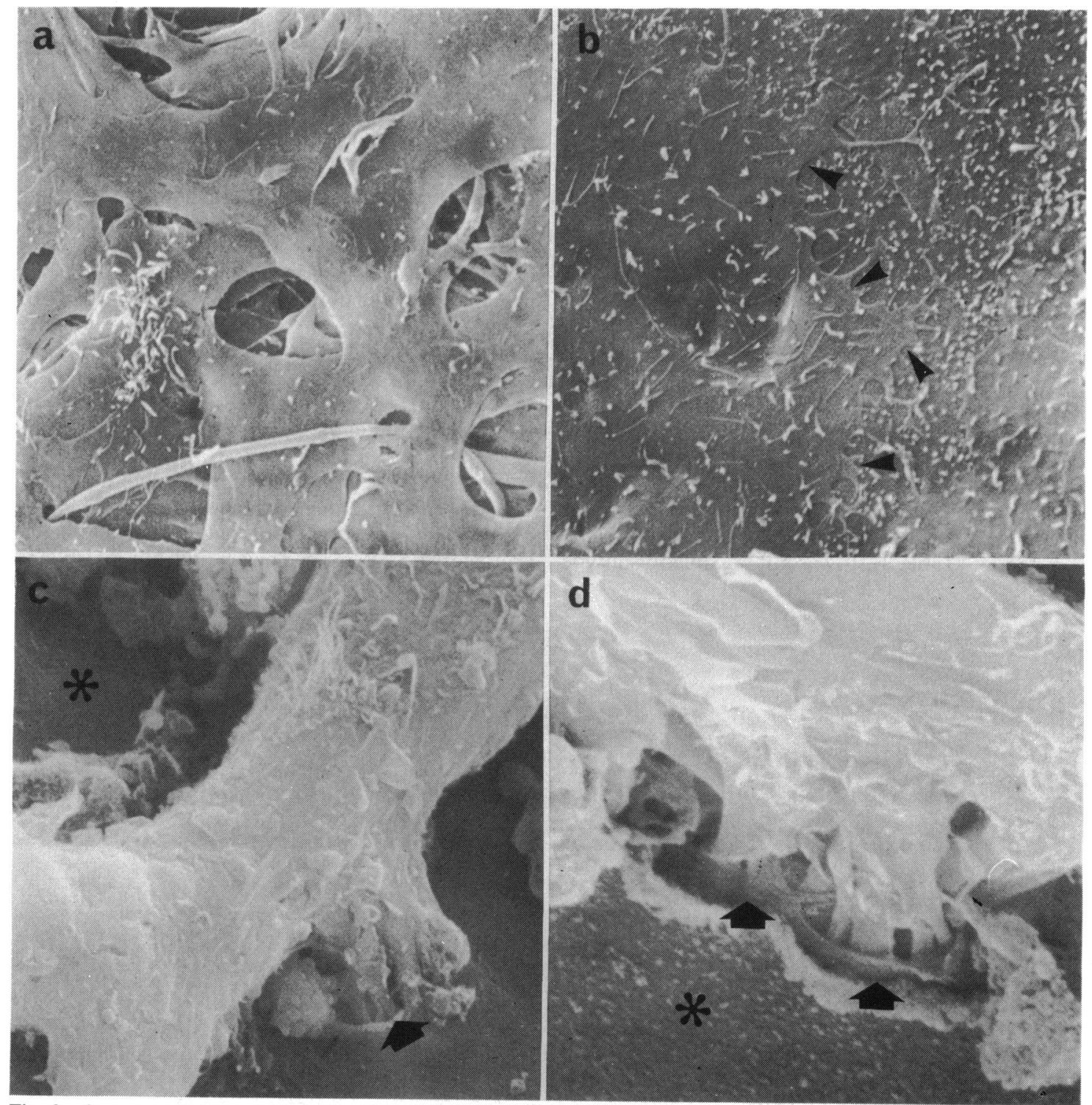

Fig. 3 Scanning electron micrographs of an epiretinal membrane: (a) Interdigitating glial cell processes incompletely cover the retinal surface, leaving patches of 'bare' inner limiting lamina. $(\times 2470)$. (b) Glia completely cover the retinal surface in another area. Glial cells are overlapping one another (arrowheads). ( $\times 2880)$. (c) and (d) Glial cell processes extend through defects in the inner limiting lamina (arrows). Note that the retinal surface is not distorted (asterisks). ( $\times 2470$ and $\times 4940)$.

were not associated with retinal distortion or detachment (Table 1) essentially consisted of glia only or glia plus inflammatory cells. In three of these eyes processes of GFAP-positive epiretinal cells were identified occupying breaks in the inner limiting lamina (ILL). Scanning electron microscopy of one such eye showed a sheet of epiretinal glial cells with multiple extensions through the ILL (Fig. 3a-d).

The two epiretinal membranes associated with retinal puckering and four of the seven membranes over detached, folded retina had a glial component (Fig. 1c). However, all these membranes also contained a prominent fibrous component - that is, fibroblast-like, GFAP-negative cells embedded in collagen 
-at the site of membrane contraction (Fig. 1c, e, f); inflammatory cells and pigment-containing cells were also identified. The glial elements of these combined fibrous and glial membranes ('fibroglial membranes') were sometimes distributed as layers (Fig. 1c). The glial tissue was typically sandwiched between the fibrous component and the ILL; in one eye, however, the glial layer was on the vitreal surface of the fibrous tissue. Alternatively, the glial component was distributed in small foci which could be demonstrated clearly only by GFAP staining (Fig. 1e, f). The glial component of two of the six fibroglial membranes was observed to be in continuity with GFAP-positive cells in the retina via defects in the ILL (Fig. 4a).

In the three eyes with no demonstrable glial component the ERMs were composed of fibroblast-like cells, inflammatory cells, and pigment-containing cells (Fig. 4b).

Peeled epiretinal membranes. Immunohistochemical study of sections from surgically excised membranes revealed that all 16 specimens had a glial component (Table 2). It was not possible to subtype the glia immunohistochemically, but electron microscopy showed the presence of typical fibrous astrocytes with their distinctive intermediate filaments (Fig. 2d). The GFAP-positive cells in these membranes were again distributed as foci or layers (Fig. 4c-f) except in four membranes with isolated cells on the ILL or scattered throughout the specimen (Table 2). However, a GFAP-negative component comprising fibrous tissue (i.e., fibroblast-like cells and collagen) was observed to occupy the bulk of the material in all specimens. Inflammatory and pigmented cells were also present in variable numbers.

Monolayers in tissue culture. Three of the five monolayers of cells derived from peeled membranes contained GFAP-positive cells (Table 2), but these glial cells represented a minority (between 2 and $20 \%$ ) of the cells in the cultures. The positively staining cells had a variety of shapes, including spindleshaped cells (Fig. 5), epithelium-like (plate-like) cells, and cells with multiple, branching processes. However, the majority of the cells had the morphological characteristics of macrophages and fibroblasts and

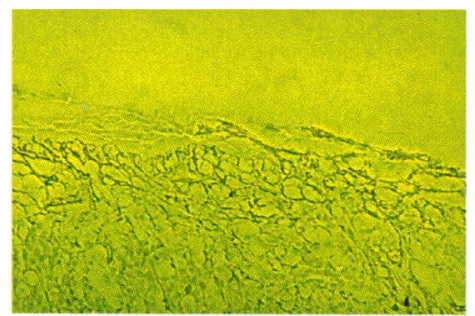

Fig. $4 \mathrm{a}$

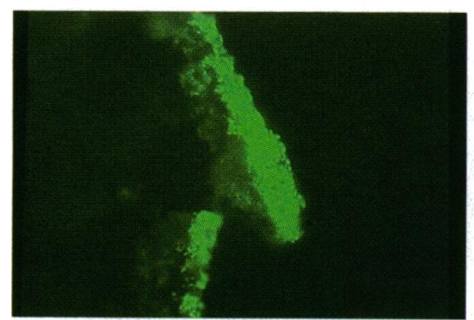

Fig. 4d

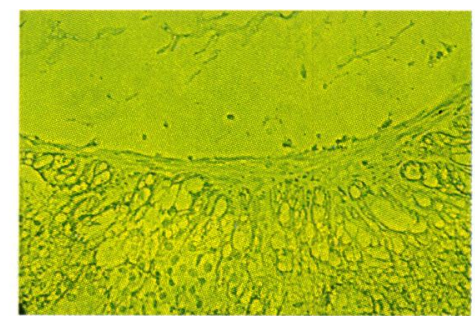

Fig. $4 b$

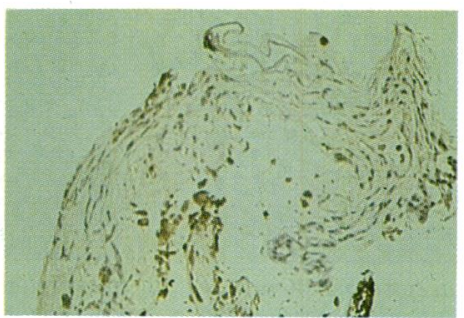

Fig. $4 \mathrm{e}$

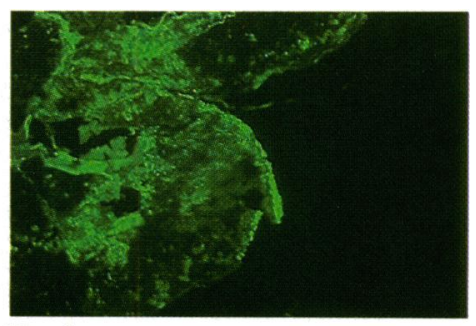

Fig. $4 \mathrm{c}$

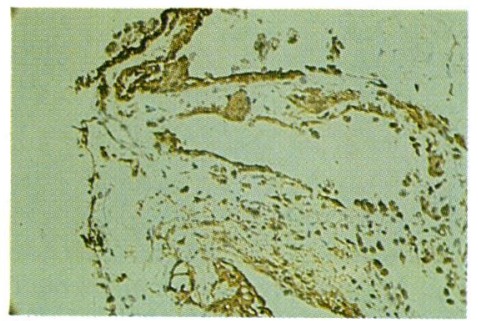

Fig. 4f

Fig. 4 (a) Positive phase-contrast micrograph of retina with an overlying epiretinal membrane, stained with the immunoperoxidase method for GFAP and counterstained with haematoxylin. Note the glial component of the fibroglial membrane continuous with intraretinal glia. $(\times 137)$. (b) Positive phase-contrast micrograph of an epiretinal membrane associated with a retinal pucker, stained with the immunoperoxidase method for GFAP and counterstained with haematoxylin. There is no glial component in this membrane. $(\times 137)$. (c) Immunofluorescence staining pattern of a frozen section of a peeled epiretinal membrane stained for GFAP. Note the layer of glial cells in the predominantly non-glial membrane. $(\times 110)$. (d) Higher power view of same specimen as plate 2(c). The layer of glia can be seen juxtaposed to the non-glial tissue. $(\times 412)$. (e) Light micrograph from a section of a peeled epiretinal membrane stained for GFAP with the immunoperoxidase method and counterstained with haematoxylin. Foci of glia are present, but the bulk of the tissue is non-glial. $(\times 69)$. (f) Light micrograph from a section of a peeled epiretinal membrane stained for GFAP with the immunoperoxidase method and counterstained with haematoxylin. The glial component is more prominent than in the specimen seen in Fig. 2(e), and is forming layers. $(\times 69)$. 
were GFAP-negative. Similarly, the two monolayers without a demonstrable glial component consisted of fibroblasts and macrophages.

\section{Discussion}

GFAP was initially isolated from cerebral tissue, ${ }^{27}$ and there is good evidence that this protein is specific to glial cells. ${ }^{2 \times}$ In addition, GFAP forms $10 \mathrm{~nm}$ filaments in vitro, indicating that it is the major subunit of the intermediate filaments of astroglia. ${ }^{29}$ However, not all glial cells can be stained with an immunohistochemical technique using antibodies to GFAP - for example, cerebral astrocytes from newborn rats ${ }^{311}$ and the radial fibres of Müller in rat retina only stain following injury. ${ }^{6}$ Positively staining cells have been found in the inner layers of the retina, at the ora serrata, and in optic nerve head of the mouse, but Müller cells do not stain. ${ }^{5}$ Similarly, normal human Müller cells are GFAP-negative ${ }^{7}$ despite the fact that they contain $10 \mathrm{~nm}$ filaments. ${ }^{31}$

Our study of normal human globes confirms that astrocytic cells and their processes in the inner retinal layers stain positively for GFAP, but Müller cells do not stain (at the concentration of antisera used) except at the ora serrata. By contrast, eyes with elevated intraocular pressure, retinal detachment, or an inflammatory reaction involving the vitreal cavity show positive staining of Müller cells. Indeed, it is difficult in these specimens to distinguish Müller cells from astrocytes and their processes, although perivascular glial cells appear to stain most intensely. Foos and Gloor showed that, during the healing of experimental retinal scars, the cytoplasmic filaments of astrocytic cells progressively increase in number, ${ }^{32}$ and this probably explains the increase in staining of astrocytes in our pathological specimens compared with normal eyes. However, such a mechanism does not explain the difference in staining pattern of Müller cells. Presumably either an unmasking process or macromolecular reorganisation causes the Müller cell filaments to stain positively, but this remains speculative.

Our immunohistochemical studies of both epi-

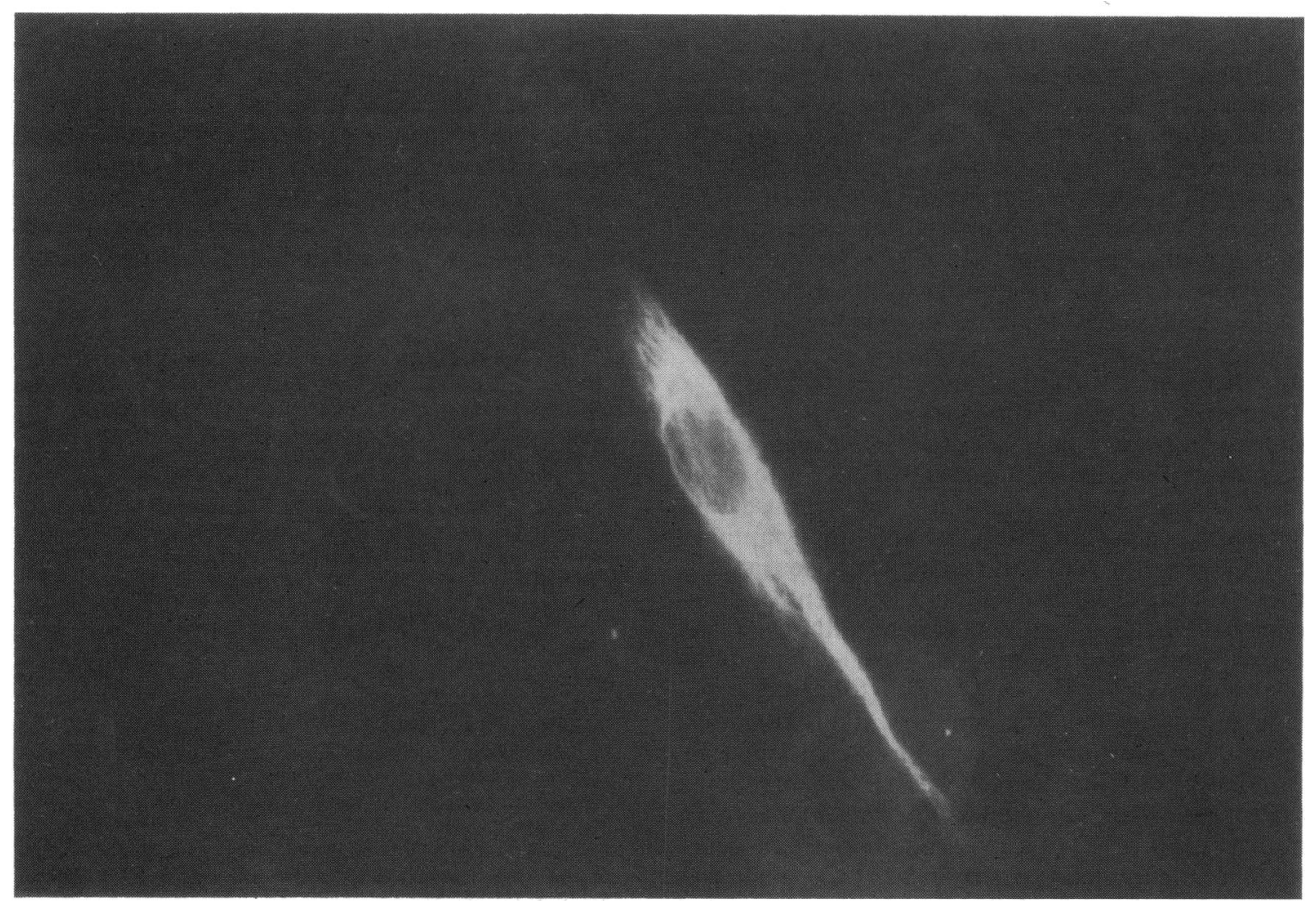

Fig. 5 An area from a cultured monolayer showing a spindle-shaped cell which is positive after immunofluorescence staining for GFAP. A filamentous staining pattern can be seen in the cell's cytoplasm. Surrounding cells are GFAP-negative and therefore cannot be seen $(\times 1090)$. 
retinal membranes 'in situ' and surgically excised specimens confirm that glial cells contribute to epiretinal membranes associated with a wide range of pathological disorders. We were also impressed by the similarity of distribution of glial elements between peeled and 'in situ' specimens. It is unlikely, therefore, that the glial cells demonstrated in peeled ERMs had been avulsed from the retina during surgery, though it is recognised that portions of ILL and Müller's end-feet are often present in such specimens. ${ }^{33}$

The specificity of the GFAP marker ensures that, when staining occurs, it is a reliable indicator of the presence of glial cells in the tissue. Cells containing pigment are a potential hazard during interpretation of immunoperoxidase staining with DAB (where pigment can be confused with the brown reaction product) and immunofluorescent staining (where pigment autofluorescence may occur). However, the staining pattern for GFAP-positive cells tends to be filamentous or homogeneous, and we found this easy to differentiate from the granular pigment.

Since glia may assume a different structural appearance (metaplasia) when displaced from their normal location, morphological criteria are often inadequate to determine their true presence or absence at the abnormal site. Epiretinal membranes frequently contain such metaplastic cells which in tissue culture may adopt an even greater variety of morphological appearances, including spindleforms ${ }^{24}$ Nevertheless, the glia still retain their GFAP content whatever their morphology in tissue culture. It is probable, therefore, that all glia-derived cells in ERMs would be GFAP-positive and that negativelystaining cells in ERMs are not of glial origin.

\section{FUNCTIONAL SIGNIFICANCE OF GLIA IN ERMS}

The role of the glial component of ERMs is open to speculation. Pure glial epiretinal membranes have been described in human globes by Foos, ${ }^{9}$ who called them 'simple' epiretinal membranes because they produced only subtle lesions and no symptoms. Furthermore, injection of retinal astrocytes into the rabbit vitreous, ${ }^{34}$ while resulting in collagen synthesis, does not lead to retinal detachment, although other experimental work suggests that glial cells may be responsible for full-thickness retinal folding. ${ }^{35}$

In our study the four globes without tractional retinal complications had only glia or glial plus inflammatory cells in the membranes. Every membrane associated with a retinal pucker or detachment had a fibroblastic (GFAP-negative) component. Indeed, in the fibroglial membranes the bulk of the tissue was non-glial, and some of the membranes associated with such complications had no glial element. Our findings do not, therefore, support the concept that purely glial membranes can cause a severe tractional event such as macular pucker or more widespread full-thickness retinal folding. Although purely glial membranes may be associated with wrinkling of the ILL, "11. 15 we believe it is the non-glial tissue which provides most of the tractional force in MPP and macular pucker. Indeed, in at least one of our globes predominantly fibrous tissue was associated with retinal puckering, while purely glial portions of the membranes overlay undistorted retina.

The distribution of the GFAP-positive cells in some ERMs suggests an alternative role for glia in ERM's. These cells often form a layer on the retinal side of the membrane upon which non-glial fibrous tissue adheres as a second lamina. The glial component in these fibroglial membranes may thus act as a scaffold on which other cells, such as perivascular fibroblasts, could migrate, proliferate, contract, or produce collagen. Immunohistochemical staining also highlights the continuity established between the glial component of an ERM and the glial 'sustentacular architecture' of the retina via dehiscences in the ILL. It is tempting to speculate that this might provide a considerable anchorage by means of which tangential traction forces on the retinal surface may be transmitted through the retina to produce full-thickness retinal folding. ${ }^{33}$

Whatever the capabilities of glial cells within ERMs, the frequency of their occurrence in these extraretinal scars suggests that they play an important role in membrane pathobiology. Indeed, control of glial proliferation may be one key to future pharmacological manipulation of epiretinal membranes.

We thank Mr R. J. Cooling, Mr P. K. Leaver, Mr Z. Gregor, and Mr A. H. Chignell, who provided many of the surgical specimens, and Professor W. R. Lec, who supplied several of the whole cyes.

Technical assistance was provided by Mr R. C. Howes, Miss E. Robins, MrJ. Prasad, and Mr R. A. Alcxander. Secretarial assistance was provided by Mrs P. Goodwin and Miss K. C. Betts.

Our research has been funded by the TFC Frost Charity Trust, the Moorficlds Locally Organised Rescarch Scheme, the Moorficlds Endowment Fund, the Wellcome Trust, and the Muirhead Settlement.

\section{References}

1 Wolter JR. The astroglia of the human retina and other glial clements of the retina under normal and pathologic conditions. Am J Ophthalmol 1955; 40: 88-99.

2 Lessells S, Kuwabara T. Retinal ncuroglia. Arch Ophthalmol 1963; 70: 671-8.

3 Ogden TE. Nerve fibre layer astrocytes of the primate retina: morphology, distribution and density. Invest Ophthalmol Visual Sci 1978; 17: 499-510.

4 Jiang Q, Fratkin JC, Blodi FC. Localization of glial fibrillary acidic protein in retinal astrocytoma: an immunohistochemical study. Curr Eye Res 1983; 8: 523-7. 
5 Bromberg JS, Schachner M. Localization of nervous system antigens in retina by immunohistochemistry. Invest Ophthalmol Visual Sci 1978; 17: 920-4.

6 Bignami A, Dahl D. The radial glia of Müller in the rat retina and their response to injury. An immunofluorescence study with antibodics to glial fibrillary acidic (GFA) protcin. Exp Eye Res 1979: 28: 6.3-9.

7 Kumpulainen T, Dahl D, Korhonen LK. Nyström SHM Immunolabelling of carbonic anhydrase isoenzyme $C$ and glial fibrillary acidic protein in paraffin-embedded tissue sections of human brain and retina. J Histochem Cytochem 1983:31: 879-86.

8 Manschot WA. Persistent hyperplastic primary vitreous: special reference to preretinal glial tissue as a pathological characteristic and to the development of the primary vitreous. Arch Ophthalmol 1958: 59: 188-203.

9 Foos RY. Vitreoretinal juncture-simple epiretinal membranes Albrecht von Graefes Arch Klin Ophthalmol 1974; 189: 231-50.

10 Bellhorn MB. Friedman AH, Wise GN, Henkind P. Ultrastructure and clinicopathologic correlation of idiopathic preretinal macular fibrosis. Am J Ophthalmol 1975; 79: 366-73.

11 Kenyon KR. Pederson JE, Green WR, Maumenec AE. Fibroglial proliferation in pars planitis. Trans Ophthalmol Soc UK 1975; 95: 391-7.

12 Rentsch FJ. The ultrastructure of preretinal macular fibrosis. Albrecht von Graefes Arch Klin Ophthalmol 1977; 202: 321-37.

13 Kenyon KR. Michels RG. Ultrastructure of epiretinal membranc removed by pars plana vitreoretinal surgery. Am J Ophthalmol 1977: 83: 815-23.

14 Van Horn DL, Aaberg TM, Machemer R, Fenzl R. Glial cell proliferation in human retinal detachment with massive periretinal proliferation. Am J Ophthalmol 1977; 84: 383-93.

15 Clarkson JG, Green WR, Massof D. A histopathic review of 168 cases of preretinal membrane. Am J Ophthalmol 1977; 84: 1-17.

16 Green WR. Kincaid MC, Michels RG, Pederson JE, Kenyon KR. Maumenee AE. Pars planitis. Trans Ophthalmol Soc UK 1981: 101: 361-7.

17 Harada T, Chauvaud D, Pouliquen Y. An electron microscopic study of epiretinal membrane of human eyes. Albrecht von Graefes Arch Klin Ophthalmol 1981; 215: 327-39.

18 Kampik A, Kenyon KR, Michels RG, Green WR, de la Cruz $\mathrm{ZC}$. Epiretinal and vitreous membranes. Comparative study of 56 cascs. Arch Ophthalmol 1981; 99: 1445-54.

19 Kampik A, Green WR. Michels RG, Rice TA. Epirctinale membranen nach photokoagulation (postkoagulative maculopathic). Ber Dtsch Ophthalmol Ges 1981; 78: 593-8.
20) Szamier RB. Ultrastructure of the preretinal membrane in retinitis pigmentosa. Invest Ophthalmol Visual Sci 1981; 21:22736.

21 Hamilton CW, Chandler D, Klintworth GK, Machemer R. A transmission and scanning electron microscopical study of surgically excised preretinal membrane proliferations in diabetes mellitus. Am J Ophthalmol 1982; 94: 473-88.

22 Baines PS. Hiscott PS, McLeod D. Posterior non-vascularized proliferative extraretinopathy and peripheral nodular retinal telangicctasis. Trans Ophthalmol Soc UK 1982; 102: 487-91.

23 Rodrigues MM. Newsome DA. Machemer R. Further characterization of epiretinal membranes in human massive periretinal proliferation. Curr Eye Res 1981; 6: 311-5.

24 Hiscott PS, Grierson I, Hitchins CA. Rahi AHS, McLeod D. Epiretinal membranes in vitro. Trans Ophthalmol Soc UK 1983; 103: $89-102$.

25 Jensen OA. Preparation of paraffin-embedded tissuc for electron microscopy. Exp Eye Res 1974; 18: 417.

26 Mukai K, Rosai J. Applications of immunoperoxidase techniques in surgical pathology. In: Fenoglio CM, Wolff M, eds. Progress in surgical pathology. New York: Masson Publishing. 1980: 1549.

27 Eng LF, Vanderhacghen JJ, Bignami A, Gerstl B. An acidic protein isolated from fibrous astrocytes. Brain Res 1971; 28: 351-4.

28 Bock E. Nervous system specific proteins. J Neurochem 1978; 30: 7-14.

29 Rucger DC, Huston JS, Dahl D, Bignami A. Formation of 10()$\AA$ filaments from purified glial fibrillary acidic protein in vitro. $J$ Mol Biol 1979; 135: 53-68.

30) Bignami A, Dahl D. Astrocyte-specific protein and radial glia in the cerebral cortex of newborn rat. Nature 1974: 252: 55-6.

31 Hogan MJ, Alvarado JA, Weddell JE. Histology of the human eye-an atlas and textbook. Philadelphia: Saunders, 1971: 393522.

32 Foos RY, Gloor BP. Vitreoretinal juncture: healing of experimental wounds. Albrecht von Graefes Arch Klin Ophthalmol 1975; 196: 213-30.

33 McLeod D, Marshall J, Grierson I. Epimacular membrane peeling. Trans Ophthalmol Soc UK 1981; 101: 170-80.

34 Burke JM. Kower HS. Collagen synthesis by rabbit neural retina in vitro and in vivo. Exp Eye Res 1980; 31: 213-26.

35 Laqua H, Machemer R. Glial cell proliferation in retinal detachment (massive periretinal proliferation). Am J Ophthalmol 1975; 80: 6() $2-18$. 